\title{
The Potential of MiRNAs as Biomarkers and Therapy Targets for Cancer
}

\author{
Teresa L. Wargasetia \\ Department of Biology \\ Faculty of Medicine Maranatha Christian University \\ Jl. Prof. drg. Suria Sumantri MPH No. 65 Bandung 40164 Indonesia \\ Email: teresa.lw@med.maranatha.edu
}

\begin{abstract}
MicroRNAs (miRNAs) are involved in the signaling circuits regulation within a cell and their deregulation plays an important role in cancer development and progression. In this review, we discussed miRNA biogenesis, miRNA function and the effect of miRNA abnormalities in cellular pathways that led to transformation of normal cells into cancer cells, as well as the indication of miRNAs as diagnostic and prognostic biomarkers of various types of cancer, as biomarkers to predict the response to cancer therapy and the potential for development of miRNAs as cancer targeted therapy.
\end{abstract}

Keywords: miRNA, cancer, diagnostic biomarker, prognostic biomarker, cancer therapy 


\title{
Potensi MiRNA sebagai Biomarker dan Target Terapi pada Penyakit Kanker
}

\author{
Teresa L. Wargasetia
}

Bagian Biologi

Fakultas Kedokteran Universitas Kristen Maranatha

Jl. Prof. drg. Suria Sumantri MPH No. 65 Bandung 40164 Indonesia

Email: teresa.lw@med.maranatha.edu

\begin{abstract}
Abstrak
MicroRNA (MiRNA) terlibat dalam regulasi penyampaian pesan dalam sel dan kelainan pada regulasi miRNA berperan penting dalam perkembangan dan progresi kanker. Pada tulisan ini dibahas mengenai biogenesis miRNA, fungsi miRNA, dan efek kelainan regulasi miRNA pada jalur di dalam sel yang mengarah kepada konversi sel normal menjadi sel kanker. Juga dibahas indikasi miRNA sebagai biomarker diagnosis dan prognosis berbagai kanker, biomarker untuk prediksi respons terapi kanker, serta potensi untuk mengembangkan terapi kanker dengan miRNA sebagai target.
\end{abstract}

Kata kunci: miRNA, kanker, biomarker diagnosis, biomarker prognosis, terapi kanker 


\section{Review Article}

\section{Pendahuluan}

MicroRNA (miRNA) adalah asam ribonukleat yang tidak mengkode protein dengan transkrip akhir sepanjang 18-25 nukleotida yang berinteraksi dengan target gen yang mengkode mRNA. miRNA bekerjasama dengan elemen pengatur lain seperti faktor transkripsi untuk mengontrol translasi mRNA. ${ }^{1}$ Kebanyakan miRNA dikode pada bagian genom yang dulu dianggap sebagai daerah bukan pengkode. Sejak ditemukan pertama kali di tahun 1993 pada cacing Caenorhabditis elegans ${ }^{2}$, miRNA menarik perhatian karena ciri fungsional yang unik dan cara kerjanya, memberi sebuah dimensi baru terhadap dogma sentral biologi molekuler. ${ }^{3,4}$ Gen-gen miRNA tersebar di dalam genom dan diperkirakan berjumlah 2-5\% dari gen-gen manusia. ${ }^{2}$ MiRNA sering diekspresikan sebagai transkrip polisistronik. ${ }^{5}$ Satu miRNA dapat mempunyai banyak mRNA target sehingga diperkirakan bahwa lebih dari 1/3 gen-gen manusia diatur oleh miRNA. ${ }^{3}$ Dewasa ini lebih dari 1.500 miRNA telah dikarakterisasi dan jumlah gengen yang telah diketahui diatur oleh miRNA pada manusia telah meningkat pesat. ${ }^{6,7}$

Kurang lebih sepertiga miRNA pada manusia berada dalam 113 kelompok yang terdiri dari 2-7 gen dengan jarak antar gen miRNA dalam kelompok yang sama adalah $\leq 51 \mathrm{~kb}$. Data profil miRNA dari berbagai jaringan dan lini sel memperlihatkan kelompok-kelompok miRNA tersebut diekspresikan bersama-sama., ${ }^{5,8}$ Gen-gen miRNA lainnya dipotong dari intron gen-gen pengkode protein, intron dan ekson dari gen bukan pengkode protein, atau dari 3'-UTR gen-gen pengkode protein dan diekspresikan secara individual. ${ }^{8}$

Peran miRNA sebagai molekul pengatur utama yang mengontrol berbagai proses dasar dalam sel, seperti proliferasi, kematian, diferensiasi, apoptosis, motilitas, sifat invasif, respons terhadap stres dan sebagainya terus dipelajari di hampir semua lingkup biologi dan biomedis. ${ }^{3,9}$

Pada tulisan ini dibahas biogenesis miRNA, fungsi miRNA, dan kelainan regulasi miRNA pada penyakit kanker. Peran miRNA sebagai biomarker diagnosis dan prognosis berbagai kanker, biomarker untuk prediksi respons terapi kanker, serta potensi untuk mengembangkan terapi kanker dengan miRNA sebagai target diungkap dalam tulisan ini.

\section{Ekspresi Abnormal MiRNA pada Kanker}

Gen-gen MiRNA ditranskripsikan menjadi primary miRNA (pri-miRNA) oleh RNA polimerase II. Transkrip pri-miRNA adalah non-coding RNA (ncRNA) dengan struktur sekunder stem-loop yang mengandung prekursor miRNA (pre-miRNA). Transkrip pri-miRNA dipotong oleh enzim Drosha (RNA polimerase III) menjadi pre-miRNA yang diekspor ke sitoplasma oleh exportin 5, lalu diproses lebih lanjut menjadi miRNA yang matang oleh Dicer (RNA polimerase III yang ke-dua). ${ }^{10,11}$ Pada sel-sel yang normal, rasio antara pri-miRNA 


\section{Review Article}

terhadap mature miRNA mendekati satu, sedangkan pada sel-sel kanker banyak gen miRNA yang ditrankripsikan namun tidak diproses menjadi miRNA yang matang. ${ }^{11}$

Dua macam pendekatan diaplikasikan untuk identifikasi gen-gen miRNA dalam skala besar yaitu kloning dan pendekatan komputer. ${ }^{12}$ Perkembangan dalam teknologi kuantifikasi miRNA, seperti miRNA microarray, bead-based flow cytometry, RNA-primed array-based Klenow enzyme (RAKE) assay, miRNA serial analysis of gene expression (miRAGE), and realtime RT-PCR based TaqMan miRNA assay telah memfasilitasi studi profil miRNA global pada genom kanker. ${ }^{13}$ MiRNA dapat menjadi penanda molekuler yang akurat karena relatif stabil mengingat ukurannya yang kecil dan resisten terhadap degradasi RNAse. miRNA dapat diisolasi dari spesimen formalin-fixed paraffin-embedded (FFPE) dan dikuantifikasi dengan qRT-PCR dan microarray. Perkembangan metode qRT-PCR yang sangat sensitif memungkinkan deteksi miRNA dari beberapa nanogram total RNA yang diperoleh dari biopsi aspirasi jarum halus. ${ }^{2,14}$

Beberapa tahun terakhir ini dipelajari bahwa sejumlah miRNA berperan dalam patogenesis berbagai kanker pada manusia. Fungsi miRNA yang hilang/menurun atau sebaliknya berupa fungsi mRNA yang meningkat berkontribusi terhadap perkembangan kanker. Lebih dari setengah gen-gen miRNA pada manusia berlokasi pada daerah genomik yang sering mengalami amplifikasi, delesi, dan translokasi terlibat dalam kanker. ${ }^{13,15,16}$ Bukti pertama keterlibatan miRNA dalam kanker dilaporkan pada 2002, saat Calin menemukan dua gen miRNA yaitu miR-15a dan miR-16-1 pada daerah di kromosom 13q14 yang biasanya mengalami delesi pada leukemia limfositik kronik. Hilangnya miR-15a dan miR-16-1 terjadi pada hampir 70\% leukemia limfositik kronik. ${ }^{13}$ Delesi atau penurunan ekspresi miR-15a dan miR-16-1 juga ditemukan pada kanker prostat, limfoma, dan mieloma multipel. ${ }^{16}$ Kemajuan dalam bidang penelitian kanker memberikan informasi bahwa kelainan regulasi ekpresi miRNA ditemukan pada sejumlah kanker manusia seperti leukemia, limfoma, glioblastoma, kanker kolon, kanker paru, kanker payudara, kanker prostat, kanker tiroid, kanker serviks, dan kanker ovarium. $^{13}$

Profil ekspresi abnormal miRNA ditemukan pada spesimen tumor dan lini sel kanker ketika dibandingkan dengan kontrol jaringan normal. ${ }^{3}$ MiRNA berikatan secara spesifik dengan targetnya, sehingga polimorfisme nukleotida tunggal (single nucleotide polymorphism, SNP) pada urutan miRNA atau mRNA target dapat mengarah kepada suatu penyakit, termasuk kanker. ${ }^{17}$ Pada berbagai tipe kanker didapati pengaturan yang salah pada miRNA yang mengindikasikan bahwa miRNA mempengaruhi gen-gen target yang terlibat dalam proliferasi sel, apoptosis, diferensiasi, invasi, dan motilitas yang penting untuk perkembangan kanker. Contoh miRNA yang diekspresikan abnormal pada kanker ditampilkan pada tabel di bawah ini. ${ }^{3}$ 


\section{Review Article}

Tabel 1 Ekspresi Abnormal MiRNA pada Kanker ${ }^{3}$

\begin{tabular}{|c|c|c|}
\hline Tipe Kanker & Peningkatan Ekspresi & Penurunan Ekspresi \\
\hline Kanker payudara & $\begin{array}{l}\text { miR-10b, miR-21, miR-22, miR27a, miR- } \\
\text { 155, miR-210, miR-221, miR-222, } \\
\text { miR-328, miR-373, miR-520c }\end{array}$ & $\begin{array}{l}\text { let-7, miR-9-1,miR-17/miR-20, miR-31, } \\
\text { miR-125a, miR-125b, miR-146, } \\
\text { keluarga miR-200, miR-205, miR-206, } \\
\text { miR-335 }\end{array}$ \\
\hline $\begin{array}{l}\text { Leukemia } \\
\text { limfositik } \\
\text { kronik }\end{array}$ & miR-21, miR-155 & $\begin{array}{l}\text { miR-15, miR-16, miR-29b, miR-29c, miR- } \\
\text { 34a, miR143, miR-145, miR-181b, miR- } \\
223\end{array}$ \\
\hline Kanker paru & $\begin{array}{l}\text { kelompok miR-17-92, miR-21, miR-106a, } \\
\text { miR-155 }\end{array}$ & $\begin{array}{l}\text { miR-1, keluarga let-7, miR-7, miR- } \\
\text { 15a/miR-16, keluarga miR-29 }\end{array}$ \\
\hline Limfoma & kelompok miR-17-92, miR-155 & miR-143, miR-145 \\
\hline Kanker prostat & miR-221, miR-222 & $\begin{array}{l}\text { kelompok miR-15a-miR-16-1, miR-101, } \\
\text { miR-127,miR-449a }\end{array}$ \\
\hline Glioblastoma & miR-21, miR-221, miR-222 & $\operatorname{miR}-7$ \\
\hline $\begin{array}{l}\text { Karsinoma } \\
\text { hepatoseluler }\end{array}$ & $\begin{array}{l}\text { kelompok miR-17-92, miR-21, miR-143, } \\
\text { miR-224 }\end{array}$ & miR-1, miR-101, miR-122a \\
\hline Kanker kolorektal & kelompok miR-17-92, miR-21 & $\begin{array}{l}\mathrm{miR}-34 \mathrm{a}, \mathrm{miR}-34 \mathrm{~b} / \mathrm{c}, \mathrm{miR}-127, \mathrm{miR}-143, \\
\mathrm{miR}-145, \mathrm{miR}-342\end{array}$ \\
\hline Kanker lambung & miR-21, miR-27a & miR-143, miR-145 \\
\hline Kanker ovarium & $\operatorname{miR}-214$ & miR-34b/c, keluarga miR-200 \\
\hline Melanoma & miR-221, miR-222 & let-7a, miR-34a \\
\hline $\begin{array}{l}\text { Karsinoma sel } \\
\text { skuamosa } \\
\text { kepala dan } \\
\text { leher }\end{array}$ & $\operatorname{miR}-21$ & let-7d, miR-138, miR-205 \\
\hline
\end{tabular}

Perubahan pada miRNA berperan penting dalam karsinogenesis berbagai tumor. Analisis awal data berbagai tipe kanker dari konsorsium The Cancer Genome Atlas melalui cBioPortal memperlihatkan perubahan yang signifikan pada gen-gen yang terlibat dalam kerja miRNA seperti AGO2, APC, CCND1, CCNE1, CDKN2A, CHD1, CTCF, Dicer1, DNASE1, Drosha, EGFR, ERCC3, FRG1, GATA3, OR6N1, TRBP, dan XPO5. Gen AGO2 adalah gen dengan insidensi mutasi gen yang tinggi pada sejumlah kanker termasuk karsinoma invasif payudara $(23,3 \%)$, adenokarsinoma kolon dan rektum (12,3\%), karsinoma uretralial kandung kemih (20,8\%), dan adenokarsinoma prostat (20,7\%). Bukti ini menyokong laporan sebelumnya yang mengkaitkan perubahan mutasi, variasi jumlah kopi, dan/atau ekspresi mRNA yang tidak diregulasi dengan terjadinya kanker. ${ }^{18}$ 


\section{Review Article}

\section{Aspek-Aspek Biologi Kanker yang Diregulasi oleh MiRNA}

Regulasi miRNA berperan dalam berbagai peristiwa biologis kanker, yaitu:

1. Siklus sel

Gen p27 (Kip1) yang merupakan penekan tumor, menjadi target langsung dari miR-221 dan miR-222 pada glioblastoma dan kanker prostat. MiR-221 dan miR-222 yang berada di kromosom X diekspresikan berlebih pada berbagai kanker yaitu kanker ovarium, kanker hati, dan glioblastoma. ${ }^{14,19}$ Kedua miRNA tersebut mendukung pertumbuhan sel dan progresi siklus sel. ${ }^{19}$

2. Kematian sel terprogram

MiRNA berpartisipasi dalam tumorigenesis dengan menjadikan gen-gen antiapoptosis sebagai target. Sebagai contoh adalah penekanan gen-gen antiapoptosis Mcl-1 oleh miR-29b dan miR-4s, juga Bcl-2 oleh miR-15a dan miR $-16 .^{14}$

3. Invasi dan metastasis

MiR-21 yang diekspresikan berlebih pada kanker menyebabkan motilitas sel meningkat dan invasi dengan menjadikan phosphatase and tensin homolog (PTEN) sebagai target. PTEN adalah penekan tumor yang menghambat invasi sel dengan menghambat ekspresi dari matrix metalloprotease. Jalur lain dilaporkan pada kanker kolorektal bahwa miR-21 berperan dalam invasi, intravasasi, dan metastasis melalui penurunan ekspresi Pdc44. ${ }^{14}$ MiRNA lainnya yang berperan dalam invasi dan metastasis adalah miR-10b. ${ }^{14,15}$

4. Angiogenesis

Stimulasi pembentukan pembuluh darah baru oleh c-Myc melibatkan penekanan ekspresi faktor antiangiogenik Tsp-1 (thrombospondin-1). c-Myc menekan Tsp-1 melalui pengaktifan kelompok miR-17-92. ${ }^{14}$

MiRNA mempengaruhi keenam ciri sel-sel malignan yaitu kemandirian dalam sinyal pertumbuhan (keluarga let-7), tidak sensitif pada sinyal antipertumbuhan (kelompok miR-1792), menghindari apoptosis (miR-34a), kemampuan replikasi tak terbatas (kelompok miR$372 / 373)$, serta invasi dan metastasis (miR-10b). ${ }^{20}$

\section{MiRNA sebagai Biomarker Kanker}

Sebagai biomarker, microRNA dapat diukur dan dievaluasi sebagai indikator proses biologis normal atau patogenik dan respons farmakologis terhadap terapi. Untuk penyakit kanker, miRNA dapat berperan sebagai biomarker untuk deteksi dini atau diagnosis kanker, memungkinkan prediksi prognosis pasien dan efikasi terapi. ${ }^{6}$ 


\section{Review Article}

Selama ini, pengembangan molekul sebagai biomarker yang dapat diuji dari spesimen manusia mempunyai kendala berupa ketidakstabilan dan tidak resisten terhadap penyimpanan. RNAse yang terdapat pada cairan tubuh dapat mendegradasi molekul, terutama mRNA. Berita baik bahwa miRNA serum dapat tetap stabil pada pemanasan, tingkat $\mathrm{pH}$ yang sangat rendah atau tinggi, waktu penyimpanan yang lama, dan pembekuan-pencairan berulangkali. Keunikan miRNA ini menjanjikan penemuan biomarker-biomarker baru untuk diagnosis dan prognosis kanker. $^{4,21}$

Biomarker kanker harus cukup sensitif untuk dapat mengidentifikasi individu penderita kanker dan cukup spesifik untuk dapat mengetahui individu yang sehat. Sampai saat ini tidak ada biomarker yang $100 \%$ sensitif dan spesifik sehingga perlu pengujian sejumlah biomarker dalam bentuk panel. ${ }^{6}$ Tantangan utama untuk penggunaan miRNA sebagai biomarker adalah implementasi protokol yang terstandardisasi untuk isolasi dan analisis miRNA. ${ }^{7,4}$

\section{MiRNA sebagai Biomarker Diagnostik Kanker}

MiRNA dapat digunakan untuk alat diagnostik atau prognostik, karena profil ekspresi mRNA merefleksikan asal tumor, stadium, dan variabel patologis lainnya. Biomarker miRNA digunakan untuk diagnosis kanker, misalnya miR-196a tinggi pada adenokarsinoma duktal pankreas, namun rendah pada jaringan normal dan pankreatitis kronis, sedangkan miR-217 mempunyai pola ekspresi yang berlawanan. Oleh karena itu diagnosis kanker tersebut dilakukan dengan mengukur rasio miR-196a/-217 dengan qRT-PCR. ${ }^{14}$

MiR-21 diekspresikan berlebih pada glioblastoma, berlawanan dengan ekspresi yang rendah di jaringan otak normal, menunjukkan miR-21 berpotensi sebagai biomarker diagnostik untuk glioblastoma. ${ }^{3}$

MiRNA juga berguna untuk membedakan subtipe pada kanker. Analisis perbandingan pola ekspresi miRNA pada adenokarsinoma dan kanker paru skuamosa mengidentifikasi miR205 sebagai biomarker yang sangat spesifik untuk kanker paru skuamosa. ${ }^{3}$ Penelitian menunjukkan bahwa miR-155 dapat membedakan tumor payudara yang Estrogen Receptor Negative (ER-) dan Estrogen Receptor Positive (ER+). ${ }^{2}$

Merupakan informasi penting bahwa miRNA sering ditemukan di dalam mikrovesikel berukuran 50-100 nm (eksosom yang diproduksi jaringan tumor) pada darah perifer. Hal tersebut berkaitan dengan potensi miRNA di dalam darah sebagai biomarker noninvasif yang stabil di dalam serum dan plasma untuk diagnosis kanker secara dini. ${ }^{2,3,6,21}$ Lawrie et al. adalah para peneliti yang pertama kali menemukan regulasi abnormal miRNA yang bersirkulasi di dalam darah yang berkaitan dengan kanker. Mereka menunjukkan bahwa miRNA-21 banyak ditemukan dalam serum pasien diffuse large B-cell lymphoma. Profil miRNA pada pasien 


\section{Review Article}

leukemia menunjukkan bahwa kadar miR-92a dalam peredaran darah menurun dalam kasus keganasan. Penelitian lain mendapati peningkatan miR-141 dalam serum pasien kanker prostat metastasis ketika dibandingkan dengan kontrol orang sehat. ${ }^{19}$

MiRNA juga dapat dideteksi di dalam urin, saliva, dan feses. Pasien kanker kandung kemih memiliki ekspresi miR-126 dan miR-182 yang lebih tinggi pada urin dibandingkan orang normal. Ekspresi miR-125a dan miR-200a lebih rendah pada saliva pasien dengan karsinoma sel skuamosa mulut dibandingkan dengan kontrol, memperlihatkan bahwa miRNA dari saliva dapat digunakan untuk deteksi kanker oral. ${ }^{6,21}$ MiRNA pada feses telah dievaluasi sebagai biomarker untuk penapisan kanker kolorektal. MiR-21 dan miR-106a diekspresikan berlebih pada spesimen feses pasien adenoma dan kanker kolorektal. ${ }^{6}$ Untuk penelitian kanker paru-paru, miRNA dapat diambil dari sampel saliva, sputum, dan bronchoalveolar lavage. ${ }^{7}$

\section{MiRNA sebagai Biomarker Prognostik Kanker}

Profil miRNA dapat menunjukkan prognosis, misalnya ekpresi yang tinggi dari miR326/miR-130a dan ekspresi rendah miR-155/miR-210 berkaitan dengan peningkatan kemampuan bertahan hidup pasien glioblastoma. Ekspresi miR-375 ditekan pada karsinoma sel skuamosa esofagus dan berkaitan dengan stadium klinis lanjut, metastasis, dan luaran yang buruk. $^{6} \quad$ Penurunan ekspresi let-7 pada pasien non-small cell lung cancer berkaitan dengan prognosis buruk. ${ }^{5}$ Pada kanker payudara, ekspresi berlebih dari miR-21 berkaitan dengan gambaran patofisiologis penyakit seperti stadium lanjut tumor, metastasis ke kelenjar getah bening, dan kemampuan bertahan hidup yang rendah. Studi menggunakan microarray dengan probe oligonukleotida miRNA mengidentifikasi miR-21 sebagai petanda prognostik potensial untuk diagnosis kanker payudara. ${ }^{3}$

\section{MiRNA sebagai Biomarker untuk Prediksi Respons Terapi Kanker}

Kemoterapi banyak digunakan untuk pengobatan kanker, namun resistensi obat adalah masalah utama untuk keberhasilan pengobatan. Adanya berbagai mutasi dan perubahan genetik yang bervariasi menjadikan tumor tidak responsif terhadap pengobatan. Resistensi terhadap tipe obat kemoterapi tertentu dapat dipengaruhi oleh regulasi miRNA dan respons sel-sel kanker terhadap kemoterapi dapat dimodulasi oleh miRNA. ${ }^{6}$

Inhibisi miR-21 dan miR-200b meningkatkan sitotoksisitas yang diinduksi gemcitabine terhadap lini sel cholangiocarcinoma. Demikian pula inhibisi miR-21 berkaitan dengan penngkatan sensitisasi sel-sel MCF-7 (lini sel kanker payudara) terhadap topotecan, suatu agen kemoterapi untuk kanker ovarium. ${ }^{6}$ 


\section{Review Article}

Penurunan ekspresi miR-181b dan miR-21 pada kanker lambung berhubungan dengan peningkatan kemampuan bertahan hidup pasien yang mendapat pengobatan dengan 5fluorouracil-based antimetabolite $S-1$ dan doxifluridine-based regimens. Keberadaan miR-181b meningkatkan respons pengobatan dengan 5-fluorouracil-based antimetabolite S-1 dan inhibisi miR-31 meningkatkan sensitivitas terhadap 5-fluorouracil pada pasien kanker kolorektal. Ekspresi berlebih miR-215 menurunkan sensitivitas sel-sel kanker kolorektal terhadap MTX dan tomudex, sedangkan ekspresi berlebih dari miR-140 meningkatkan resistensi terhadap kemoterapi 5-fluorouracil dan MTX. ${ }^{6}$

\section{MiRNA sebagai Target Terapi Kanker}

Peran miRNA dalam inisiasi, progresi, dan metastasis pada kanker memunculkan miRNA sebagai target obat baru atau alat terapi baru. Terdapat dua strategi utama untuk menjadikan ekpresi miRNA sebagai target untuk pengobatan kanker, yaitu strategi langsung dengan menekan ekspresi miRNA onkogenik atau meningkatkan ekspresi miRNA penekan tumor. ${ }^{3,6,22}$ MiRNA dihambat dengan oligonukleotida antisense yang dimodifikasi seperti 2'-Omethyl antisense oligonuleotide dan antagomirs (komplemen oligonukleotida) ${ }^{3,14}$, sedangkan peningkatan ekspresi miRNA dengan miRNA sintetik seperti dupleks oligoribonukleotida siRNA-like. ${ }^{14}$ Strategi tidak langsung melibatkan penggunaan obat untuk memodulasi ekspresi miRNA dengan transkripsi dan pemrosesan miRNA sebagai target. ${ }^{22}$

Berbagai studi menunjukkan bahwa miRNA dapat berguna untuk terapi kanker, namun terdapat kesenjangan antara penelitian dasar dan aplikasi klinis miRNA. Penelitian preklinik dan penelitian tentang kemungkinan aplikasi klinis penting untuk meningkatkan efikasi dan menurunkan efek samping miRNA. Para ahli juga perlu menggali lebih dalam pengetahuan tentang interaksi miRNA dengan program ekspresi gen dan bagaimana interaksi ini berubah pada tumorigenesis. ${ }^{3}$

Terlalu dini untuk memprediksi apakah pemanfaatan miRNA untuk penanganan kanker dapat segera direalisasikan. Tantangan untuk menemukan formulasi terbaik dan pengiriman ke sel target yang tepat perlu diatasi. ${ }^{20}$

\section{Simpulan}

Ekspresi abnormal dari miRNA adalah fenomena yang terjadi pada berbagai kanker pada manusia. Kemampuan miRNA untuk membedakan asal tumor, subtipe, mutasi onkogenik dan predisposisi kanker, serta mengatur proses-proses penting di dalam sel membuat miRNA berpotensi sebagai biomarker diagnosis, prognosis, dan respons spesifik terhadap terapi. MiRNA memegang peranan penting pada kanker, oleh karena itu identifikasi jalur fundamental 


\section{Review Article}

di dalam sel penting untuk memberikan pemahaman yang lebih lengkap tentang fungsi dan regulasi miRNA dalam patogenesis dan progresi kanker sehingga dapat diaplikasikan secara klinis untuk terapi kanker di masa depan.

\section{Daftar Pustaka}

1. Wuchty S, Arjona D, Bozdag S, Bauer PO. Involvement of microRNA families in cancer. Nucleic Acids Res. 2012;40(17):8219-26.

2. Paranjape T, Slack F, Weidhaas J. MicroRNAs: tools for cancer diagnostics. Gut. 2009;58(11):1546-54.

3. Li M, Ding X, He M, Cheung S. MicroRNA and cancer. APPS J. 2010;12(3):309-17.

4. Ma R, Jiang T, Kang X. Circulating microRNAs in cancer: origin, function and application. J Exp \& Clin Cancer Res. 2012:38.

5. Farazi T, Spitzer J, Morozov P, Tuschi T. MiRNAs in human cancer. J Pathol. 2011;223(2):102-15 .

6. Bovell L, Putcha B, Samuel T, Manne U. Clinical implications of microRNAs in cancer. Biotech Histochem. 2011; 88(7):388-96.

7. Leidinger P, Keller A, Meese E. Micrornas - important molecules in lung cancer research. Front Genet. 2012.

8. Mendes ND, Freitas AT, Sagot MF. Survey and summary: current tools for the identification of miRNA genes and their targets. Nucleic Acids Res. 2009:2419-33.

9. Wang J, Zhang KY, Liu SM, Sen S. Tumor-associated circulating microRNAs as biomarkers of cancer. Molecules. 2014:1912-38.

10. Kala R, Peek GW, Hardy TM, Tollefsbol TO. MicroRNAs: an emerging science in cancer epigenetics. J Clin Bioinformatics. 2013;3(1):6.

11. Hulf T, Sibbritt T, Wiklund ED, Bert S, Strbenac D, Statham AL, et al. Discovery pipeline for epigenetically deregulated miRNAs in cancer: integration of primary miRNA transcription. BMC Genomics. 2011;12:54.

12. $\mathrm{Xi} \mathrm{Y,} \mathrm{Edwards} \mathrm{JR,} \mathrm{Ju} \mathrm{J.} \mathrm{Investigation} \mathrm{of} \mathrm{miRNA} \mathrm{biology} \mathrm{by} \mathrm{bioinformatic} \mathrm{tools} \mathrm{and} \mathrm{impact} \mathrm{of} \mathrm{miRNAs} \mathrm{in}$ colorectal cancer - Regulatory relationship of c-Myc and p53 with miRNAs. Ca Inform. 2007;245-53.

13. Song FJ, Chen KX. Single-nucleotide polymorphisms among microRNA: Big effects on cancer. Chin J Cancer. 2011:381-91

14. Lee Y, Dutta A. MicroRNAs in cancer. Annu Rev Patho. 2009;4:199-227.

15. Chen P, Su J, Hung M. Dysregulation of microRNAs in cancer. J Biomed Sci. 2012;19(90).

16. Bandyopadhyay S, Mitra R, Maulik U, Zhang MQ. Development of the human cancer microRNA network. Silence. 2010;1(1):6.

17. Lodes MJ, Caraballo M, Suciu D, Munro S, Kumar A, Anderson B. Detection of cancer with serum miRNAs on an oligonucleotide microarray. PLoS One. 2009;4(7).

18. Huang J-T, Wang J, Srivastava V, Sen S, Liu S-M. MicroRNA machinery genes as novel biomarkers for cancer. Front Oncol. 2014;4:113.

19. Brase JC, Wuttig D, Kuner R, Sültmann H. Serum microRNAs as non-invasive biomarkers for cancer. Mol Cancer. 2010;9:306.

20. Di Leva G, Garofalo M, Croce C. MicroRNAs in cancer. Annu Rev Pathol. 2014;9:287-314.

21. Shen J, Stass S, Jiang F. MicroRNAs as potential biomarkers in human solid tumors. Cancer Lett. 2013;392(2):125-36.

22. Iorio M V , Croce CM. MicroRNA dysregulation in cancer: diagnostics, monitoring and therapeutics. A comprehensive review. EMBO Mol Med. 2012:143-59. 